\title{
MERCHANT CASH ADVANCES: INVESTIGATING THE taXATION CONSEPUEnces In SOUTH AfRICA
}

\author{
Eduard Kilian* \\ Stellenbosch University \\ eduard.kilian@gmail.com
}

Received: July 2014

\author{
Rudie Nel" \\ Stellenbosch University \\ rnel@sun.ac.za
}

Accepted: June 2015

\begin{abstract}
The merchant cash advance is an emerging lending product designed to address the need to maintain cash flows and is essentially the business equivalent of a "payday" loan. A lump-sum advance is made by the merchant cash advance service provider to a business (the merchant) in exchange for an agreed upon percentage of future credit and/or debit card receivables. This article investigates the taxation consequences of merchant cash advance transactions in South Africa, in an attempt to provide guidance which is currently lacking. Although it is posited that a merchant cash advance is a form of debt factoring, the income tax treatment of the initial advance and the resulting discount reflect that of a loan. Through the investigation it was determined that merchants will be able to deduct the discount and processing fees from income. The merchant cash advance service provider will include such discount and processing fee in 'gross income'. The initial advance and any resulting discount are held to be a 'financial service' and therefore an exempt supply for VAT purposes, with the processing fee constituting a taxable supply.
\end{abstract}

Keywords

Debt factoring; discount; financial services; interest; loans; merchant cash advance; sale of future receivables

* Mr $\boldsymbol{\varepsilon}$ Kilian is a senior manager at TFG Financial Services, South Africa.

\# Mr R Nel is a senior lecturer at the School of Accountancy, Stellenbosch University, South Africa. 


\section{INTRODUCTION}

The merchant cash advance (MCA) is an alternative form of finance that has been increasing in popularity since the credit crisis in 2008. This form of finance is essentially the business equivalent of a "payday" loan (Bennett \& Tiku, 2008). In its most common form, a lump sum advance is made by the MCA service provider to a business (the merchant) in exchange for an agreed upon percentage of future credit and/or debit card receivables (Tozzi, 2009). A percentage of the merchant's daily credit or debit card sales is retained, either directly from the processor that clears and settles the credit or debit card payment or via a debit order from the merchant's bank account, until the obligation has been met. In common with standard debt factoring transactions, a discounting fee, as well as a processing fee, is charged (Loten, 2011).

MCAs differ from debt factoring in that debt factoring involves existing debt, while MCAs are based on future credit and debit card sales, i.e. the merchant has yet to generate sales resulting in the future receivables (such sales constituting the subject of the initial advance). At the time of the sale of the future receivables, there is therefore no right to payment by any specified customer, for any specified product or at any specified price. The risk of non-payment has also not shifted to the MCA service provider, as repayment is collected from funds actually transmitted to the merchant by customers that pay for the goods or services delivered (Weston, 2012). Many MCA service providers structure their business in a way that resembles traditional debt factoring. Transactions are often designed as purchases and sales of future receivables between an MCA service provider and a merchant (Weston, 2012). In this manner MCA service providers endeavour to distinguish their product offering from traditional loans. MCA service providers therefore claim that they are not bound by legislation that would affect loans, for example the limiting of interest rates (Farrel, 2008). The classification of an MCA as a loan could affect the protection granted to the consumer, for example under the National Credit Act No. 34 of 2005. Furthermore, such classification could also have an impact on how these transactions are treated from a taxation perspective.

According to Bennett and Tiku (2008), there are now more than 50 companies in the USA issuing cash advances to small businesses. There are still relatively few MCA service providers in South Africa. Retail Capital Proprietary Limited, Merchant Capital Proprietary Limited and Everest Merchant Funding Proprietary Limited are among the South African companies specialising in offering MCAs. As an indication of the extent of the industry in South Africa, since being launched Retail Capital Proprietary Limited had already processed more than R60 million in advances during 2011 and 2012 (Hubbard, 2012).

The research presented in this article stems from the fact that the market for MCAs in South Africa as an alternative form of finance may expand further in future and currently there are no guidelines in respect of the taxation consequences. The taxation consequences could, however, be affected by the classification of the MCAs as a form of debt factoring or as loans. It is therefore necessary to consider the relevant events in an MCA agreement as starting point (see FIGURE 1).

Based on the events in an MCA agreement (FIGURE 1) it is evident that the initial advance and subsequent settlement reflect the attributes of a loan. However, the fact that settlement is based on certain future receivables may be indicative of a form of debt factoring. Difficulty with such classification has also been highlighted in the American case of Advanceme Inc. (Richard B. Clark v. Advanceme, Inc., No. 2:2008cv03540 C.D. Cal. 2011) without there being any definitive guidance from the court (Weston, 2012). 


\begin{tabular}{|c|c|c|c|}
\hline Event 1 & Event 2 & Event 3 & Event 4 \\
\hline $\begin{array}{l}\text { Initial advance to } \\
\text { merchant } \\
\text { (discounted future } \\
\text { receivables) }\end{array}$ & $\begin{array}{c}\text { Processing fee paid } \\
\text { by merchant }\end{array}$ & $\begin{array}{l}\text { Subsequent sales by } \\
\text { merchant } \\
\text { (future receivables } \\
\text { contemplated in } \\
\text { Event 1) }\end{array}$ & $\begin{array}{l}\text { Settlement of initial } \\
\text { advance by merchant } \\
\text { (by means of payment for } \\
\text { sales contemplated in } \\
\text { Event } 3 \text { ) }\end{array}$ \\
\hline
\end{tabular}

FIGURE 1: Relevant events in an MCA agreement

Source: Compiled by authors

\section{RESEARCH OBJECTIVE, RESEARCH METHOD AND VALUE OF THE RESEARCH}

In writing this article the objective was to investigate the taxation consequences of MCAs in South Africa in order to develop a summary that could provide guidance regarding the taxation consequences. The objective is achieved in the following consecutive steps:

- Concluding on the classification of MCAs as a form of debt factoring or as loans. According to Weston (2012), MCA agreements can traditionally be classified in two ways: bona fide loans or the purchase of future credit and/or debit card receivables. Firstly, a comparison is made between the product features of an MCA and that of debt factoring. Secondly, a comparison is made between the product features of an MCA and a loan. Based on these comparisons a conclusion is submitted on the possible common law classification of an MCA; and

- Investigating the taxation consequences based on the relevant events in an MCA agreement.

The research method adopted is a literature review. In order to conclude on the classification of MCAs (either as a form of debt factoring or as loans), relevant case law, literature relating to MCA service providers as well as accounting literature were reviewed. In order to conclude on the taxation consequences, the relevant legislation in the Income Tax Act, 58 of 1962 (hereinafter 'the Act'), and the Value-Added Tax Act, 89 of 1991 (hereinafter 'the VAT Act'), were analysed.

The value of the research lies in the guidance it could provide regarding the taxation consequences of MCAs, in the light of the current lack of definitive guidance on the topic.

\section{COMPARISON BETWEEN MCA AGREEMENTS AND DEBT FACTORING}

The MCA can be described as a purchase from the merchant of the future debit or credit card payments for receivables generated by sales that the merchant will generate. Repayment of the advance is based on the merchant's sales volume. An agreed upon percentage of the merchant's daily credit and/or debit card sales is retained in favour of the MCA provider, until the debt obligation has been met, usually between six to eight months (Risk and Fraud Management Committee of the Electronic Transactions Association, 2008). MCAs are usually also concluded on a non-recourse basis, unless the agreement between the parties stipulates otherwise (Loten, 2011). 
With both debt factoring and MCAs, cash is advanced to the merchant when the agreement is concluded. The factor and the MCA service provider do not advance the full value of the current or future receivables purchased, but a lower percentage representing a discounting charge (First Data, 2012). Ancillary services are not typically provided by the MCA service provider to the merchant, as is the case in most debt factoring agreements, as the customer-merchant relationship is not in existence at the time of the sale to the customer (Ernst \& young, 2009).

To classify the MCA transaction as a form of debt factoring, a comparison must be made between the elements or steps followed in an MCA and a debt factoring transaction. The basic elements of a debt factoring transaction are (i) the sale of debt, (ii) the transfer of a sum of money and (iii) the collection of debt. Each of these elements is now compared to the features of MCAs in order to conclude on the classification of an MCA.

\subsection{Sale of debt}

In Syfrets Bond Participation Bond Managers Ltd v CSARS (2001) 63 SATC 1, guidelines were provided to assist in identifying the sale of a financial asset as a true 'sale'. The first requirement of a sale is an identifiable commodity or merchandise. Secondly, a price or reward must be specified. Marais JA, the judge in the said case, further confirmed that debt factoring transactions in which debts are sold at a discount to their face value are sales and not loans. It needs to be investigated whether the same holds true for an MCA, however.

With debt factoring and MCA agreements, the identifiable commodity is the recorded debt. The predominant difference between MCAs and traditional debt factoring is that debt factoring involves existing debt, while MCAs are based on future credit and debit card sales, as the merchant has yet to generate income for the future receivables to come into existence (Bennett \& Tiku, 2008). The sale of the existing or future debt is carried out by means of a cession of debt. Joubert JA in First National Bank of SA Ltd v Lynn NO \& others (1996) (2) SA 339 (A) expressed his agreement with the principle that the parties may reach an agreement to cede and transfer a future or contingent right of action, or a future or conditional debt. Future rights can therefore be transferred and the first element involved in an MCA transaction, i.e. the cession of debt, will therefore be similar to debt factoring for the purposes of classifying the transaction as a sale of debt.

\subsection{The transfer of a sum of money}

The MCA service provider advances a sum of money to the merchant in return for the purchase of future debt. The second requirement enunciated by Marais JA, in the case of Syfrets Bond Participation Bond Managers Ltd v CSARS, is that a price or reward must be specified for the debt purchased in order for it to be classified as a sale. MCA agreements specify a purchase price for the future debt sold. This requirement is also satisfied and the nature of the MCA and debt factoring agreement is therefore similar.

\subsection{Collection of debt}

The MCA service provider collects a percentage of the future sales of the merchant (Tozzi, 2009). Debt factoring may involve the collection of debt from the customers of the merchant or directly from the merchant (Ernst \& Young, 2009). With MCA agreements, the MCA service provider 
collects monies due directly from the merchant (Nectar Cash-flow Advances, 2012). A collection process is therefore present with both debt factoring and MCA transactions.

In conclusion, the basic elements of a debt factoring transaction are present in an MCA. The most important difference noted between debt factoring and an MCA is that debt factoring relates to the sale of existing receivables, whereas the MCA relates to the sale of future receivables. However, the possible classification of an MCA as a loan must be investigated before a conclusion regarding the classification of an MCA can be made.

\section{COMPARISON BETWEEN MCA AGREEMENTS AND LOANS}

According to the Concise 0xford Dictionary (2012), the two key characteristics of a loan are (i) that something is borrowed, and (ii) that this 'thing' must be repaid with 'interest'. Each of these characteristics is discussed below and compared to the features of MCAs.

\subsection{Something is borrowed}

The accounting treatment of an MCA, from the perspective of the merchant, resembles that of a loan, as a liability is initially recorded for the future receivables that must be paid to the MCA service provider (Kilian, 2014). However, the accounting treatment can at most be regarded as indicative of a loan and is not conclusive; tax law should thus be consulted for further guidance.

In ITC 968 (1961) 24 SATC 726(F) the court determined that the transaction of discounting the promissory notes was legally a sale of the notes and not a loan. The MCA service provider purchases receivables payable to the merchant by the credit or debit card processor when credit or debit cards sales are made. In common with non-recourse debt factoring agreements, the MCA service provider does grant the merchant the use of its funds until sales are made by the merchant to enable receivables to come into existence. However, the MCA service provider does not advance funds in order to lend money to the merchant, but rather makes an outright purchase of future receivables for which payment by the merchant is delayed as it depends on sales that must still occur (First Data, 2012). The MCA agreement differs from a traditional loan in that ownership of a financial asset is transferred, as opposed to money being borrowed when a loan is granted. Goldin (2007) also highlights that the other main differences between an MCA transaction and a traditional loan are that it has no fixed period for repayment, there are no fixed monthly instalments and the MCA service provider has no right of recourse against the merchant.

Although, in principle, the argument advanced favours an MCA not being regarded as something borrowed (indicating that it is not a loan), the consideration of any associated interest is also warranted, as the presence of interest could result in the MCA being regarded as an interestbearing instrument for income tax purposes.

\subsection{Interest}

Interest is charged on traditional loans as compensation for the use of the lender's money. MCA agreements typically do not refer to interest being charged. According to First Data (2012), in a typical MCA agreement the merchant agrees to remit to the MCA service provider an amount in excess of the 'selling price' of the future receivables. This excess payment present in MCA 
agreements may represent 'interest'. In ITC 1587 (1995) 57 SATC 97, the discount fee charged by a debt factor was determined to constitute or to be akin to 'interest'.

The Concise Oxford Dictionary (2012) defines a 'discount' as a deduction from the amount of a bill of exchange by a person who gives value for it before it is due. The transferor (cedent) of a debt security incurs a discounting cost in order to receive payment from the transferee (cessionary) of existing or future debts owing by third parties. The discount earned by the MCA service provider or the debt factor is therefore compensation for providing funding to the merchant and, as such, could be regarded as 'interest'. Based on the presence of 'interest' in an MCA and the fact that the MCA agreement would be an 'instrument' as contemplated in section 24J(1) an MCA would therefore be regarded as an 'interest-bearing instrument'. It is consequently submitted that section 24J will apply to the MCA transaction. In this respect the tax treatment would be similar to that of a loan, as opposed to debt factoring.

In conclusion, based on the analysis in the current and preceding section, it is submitted that from a common law perspective the typical MCA agreement could not be regarded as a mere loan agreement, as there are notable differences between these agreements. The most notable of these differences is that a transfer of ownership of a financial asset is present in an MCA agreement, which is not the case with a traditional loan, where funds are merely lent. The sale of an asset has therefore taken place in an MCA agreement, as opposed to a mere loan being granted. MCA agreements are therefore regarded as a specialised form of debt factoring. However, it is evident that an MCA and debt factoring differ in respect of whether existing receivables or future receivables are transferred. Furthermore, an MCA also demonstrates some characteristics of a loan in the form of the initial advance which is subsequently settled. The income tax and value-added tax implications are now investigated from the perspective of the merchant and the MCA service provider, respectively, in order to formulate possible guidance on the tax consequences.

\section{INCOME TAX CONSEPUENCES}

Based on the relevant events of an MCA (indicated in FIGURE 1 ) the income tax consequences for the merchant and the MCA service provider are investigated based on relevant sections in the Act and interpretation based on case law.

\subsection{Amounts received or earned by the merchant}

\subsubsection{Initial advance}

The initial MCA the merchant receives is the selling price of the right to future receivables sold to the MCA service provider. The initial advance constitutes a receipt for the merchant; however, the merchant assumes the obligation to repay the amount. As the obligation to repay the amount is assumed, the receipt does not form part of 'gross income', as it would not be regarded as having been 'received by' the merchant (CIR v Genn \& Co (Proprietary) Limited (1955) 20 SATC 113). Applying the objective approach, any underlying obligation to repay or redeliver, based on either a contractual or delictual obligation, or for that matter any other action in terms of a statutory or common law, should indicate that the amount is not received for purposes of 'gross income' (Chawira, 2011). The obligation undertaken by the merchant to forfeit future income would result in the initial advance not constituting 'gross income' for the merchant. To this 
extent the treatment would reflect that of the capital repayable on an ordinary loan and not traditional debtor factoring, consequently supporting the claim that the advance should be regarded as capital in nature and subjected to capital gains tax.

The merchant, in receiving the initial cash advance, forfeits a right to receive future income in the form a payment by its customers or clients and therefore disposes of a capital asset (a right). The fact that an MCA agreement is concluded as a means of financing would merit the argument in favour of an intention to merely realise a capital asset, instead of a profit-making intention. The mere realisation of such capital asset is regarded as capital in nature if it is not in pursuance of a profit-making scheme (Elandsheuwel Farming (Edms) Bpk v SBI (1978) 39 SATC 163). The sale of the future receivables by the merchant is thus a disposal of a capital asset in respect of which a capital gain or loss may be realised. The initial advance would, however, qualify as a debt issued to the merchant and, according to paragraph $11(2)(d)$ of the Eighth Schedule, would therefore not be regarded as a disposal for capital gains tax purposes. Consequently, it would not result in any capital gains tax consequences for the merchant.

\subsubsection{Subsequent sale of goods or rendering of a service}

Subsequent to the initial advance, the merchant earns income from sale of goods or rendering of services to its customers. Sales will be made that give rise to the credit or debit card receivables which have been ceded to the MCA service provider. It therefore needs to be determined whether the income is ceded before or after it accrued to the merchant. If ceded before accrual, it would not be included in the 'gross income'; however, if ceded after accrual, it would still be included in 'gross income' (Moodie v CIR (1993) 55 SATC 164; CIR v Witwatersrand Association of Racing Clubs (1960) 23 SATC 380).

It is evident that an MCA and debt factoring differ in respect of whether existing receivables are transferred or future receivables are transferred. In traditional debt factoring, existing receivables are transferred, which indicates that the underlying income has already accrued to the merchant on initial recognition of the receivables being transferred. In contrast, future receivables are the subject of an $M C A$, in which case the underlying income will accrue in future. As held in ITC 1378 (1983) 45 SATC 230 (T), a contingent or future right or spes (in the case of an MCA, the future receivable) is capable of effective cession so as to vest the right in the cessionary. According to De Koker and Williams (2013), a cession of income will transfer the right of the cedent to the cessionary, if the cession is structured in such a way that the cedent has no right to claim the future income. With an MCA, no legal or contractual right to the income is therefore transferred to the MCA service provider on the date of the agreement. The MCA agreement does not create a prior entitlement of the MCA service provider to the future sales generated by the merchant, but only to the future receivables created by such sales. It is submitted that although the MCA agreement is concluded before the sales which bring the subject matter into existence, the cession applies only to the credit or debit card receivables that are created by the sale and not the sale itself. These receivables only come into existence after the merchant concludes the sales or renders the services, hence the income first accrues to the merchant and thereafter a percentage of the receivables created are ceded. The merchant would thus be regarded as being entitled to these amounts as they were not ceded prior to accrual (also as held in CIR $v$ Witwatersrand Association of Racing Clubs).

The merchant would thus include amounts accrued in respect of subsequent sales in 'gross income' as defined in section 1 of the Act, as such amounts would be regarded as having accrued to the merchant in a scheme of profit-making in the furthering of its ordinary trade. 


\subsection{Expenditure incurred by the merchant}

The merchant incurs the processing fee and discount as expenditure in terms of an MCA agreement. The expenditure will be actually incurred as the merchant pays the processing fee and incurs the discount as stipulated in the MCA agreement. Furthermore, the expenditure would not be regarded as capital in nature as it would not provide the merchant with any enduring benefit (BP Southern Africa (Pty) Ltd v CSARS (2007) 69 SATC 79). The key questions affecting the deductibility would therefore be whether (or not) the discount is incurred in carrying on a trade and in the production of income.

\subsubsection{Processing fee}

A processing fee is incurred by the merchant when the MCA service provider purchases the future receivables at a discount, representing a fee charged by the MCA service provider to the merchant for collecting the amounts due and arranging the agreement (First Data, 2012). The purpose of obtaining the MCA is to obtain working capital for the business. The processing fee incurred is therefore incidental to the income-producing activities of the merchant and as there is a close connection between the expenditure and the income-earning operations, the processing fee may be deducted from the merchant's income in terms of section $11(a)$.

\subsubsection{Discount}

In ITC 1628 (1997) 60 SATC 33, it was held that losses sustained because of the early discounting of promissory notes intended to produce working capital in fact related to the income earning activities of the taxpayer. Furthermore, in CSARS v Creative Productions (Pty) Ltd (1999) 61 SATC 106 , a distinction was made between money spent in creating or acquiring a source of profit and money spent in working the concern for present production of profits. Applying these principles to the MCA transaction, the merchant incurs discounting expenditure with the purpose of obtaining working capital and therefore the discounting expenditure could be regarded as being incurred in the production of income.

According to Davis, Olivier and Urquhart (2012), when trade debts are ceded with the purpose of financing trading activities, the difference between the face value of the debts and the purchase price, referred to as a discount, is akin to interest and is deemed to be sufficiently close to the income-earning operations in order to regard it as part of the cost thereof. The merchant will be regarded as the 'issuer' in respect of the interest for the purpose of section $24 J(2)$ and would qualify for a deduction in terms of this section and not in terms of section $11(a)$.

\subsection{Amounts received or earned by the MCA service provider}

The MCA service provider receives the processing fee and earns a discount as a result of the MCA. For inclusion of these amounts the 'gross income' definition would need to be consulted, except where the special inclusion in terms of 24J(2) could apply in respect of the discount. In Lategan $v$ CIR 2 SATC 16 and CIR v People's Stores (Walvis Bay) (Pty) Ltd (1990) 52 SATC 9 it was confirmed that an amount accrues to a taxpayer in the tax year that the taxpayer becomes entitled to such income. The MCA service provider becomes entitled to the processing fee and discount when the MCA agreement is concluded and the advance is made. 


\subsubsection{Processing fee}

The processing fee will therefore be included in 'gross income' if it is not of a capital nature. In ITC 31 (1924) 2 SATC 52(C) it was held that if debts are purchased and an amount is collected in excess of what was paid, it was done in the furtherance of the enterprise and is therefore income in nature. Therefore, if the purpose of the MCA service provider in purchasing the future receivables is in pursuance of a scheme of profit-making the proceeds will constitute income. By entering into the MCA agreement, it is the intention of the MCA service provider to make a profit, i.e. the purchased amount or amount collected by the MCA service provider over the term of the agreement will be in excess of the purchased amount or receivables purchased. The processing fee is therefore earned by virtue of a scheme of profit-making and will be included in 'gross income'.

\subsubsection{Discount}

The discount could be regarded as interest, as the definition of 'interest' in section 24J(1) of the Income Tax Act includes the '... discount or premium payable or receivable in terms of or in respect of a financial arrangement'. Accordingly, if the MCA service provider is regarded as the 'holder', section 24J(3) would be applied using the yield-to-maturity method (and not the general accrual principles in the 'gross income' definition). The application of section 24J(3) would depend on whether or not the MCA provider is a company and, if the provider is a person other than a company, the term of the underlying arrangement. Although the MCA service provider typically tries to collect the advance within one year (Risk and Fraud Management Committee of the Electronic Transactions Association, 2008), the collection period may also exceed one year as an MCA agreement may also have no fixed repayment term (Goldin, 2007).

If it is assumed that the term of an MCA exceeds one year, section 24J(3) of the Act would apply, instead of general inclusion in terms of 'gross income', whether or not the MCA provider is a company (definition of an 'income instrument' in section 24J(1)). Section 24J(3) prescribes that interest accrues on a day-to-day basis using a yield-to-maturity methodology and applies to all instruments as defined. As an MCA agreement may not include a specific repayment date (First Data, 2012), it may be problematic to determine the exact date of redemption as the merchant continues to forego a percentage of the receivables collected, until the original amount advanced plus the discounting profit has been settled. As section 24J defines the 'date of redemption', where the terms of that instrument do not specify a date, as the date on which, on a balance of probabilities, all liability to pay all amounts in terms of that instrument is likely to be discharged, it is submitted that the date of redemption can be based on the volume of sales transactions of the merchant. When an MCA service provider provides an advance to a merchant, one of the key factors that are considered in determining the quantum of the advance provided is the sales history of the merchant. Applying the factor of future receivables that will be collected to the expected sales of the merchant from the date of inception of the agreement, a maturity date can therefore be estimated when, based on a balance of probabilities, the merchant advance is expected to be settled (Everest Merchant Funding (Pty) Ltd, 2011). Section 24J(3) will therefore apply where the MCA provider is a company and, where the MCA provider is not a company, if the term is likely to exceed a year.

If it is assumed that the MCA provider is not a company and the term of an MCA does not exceed one year, the general inclusion in terms of 'gross income' would apply and not section 24J(3). The income in the form of the discount would be included in the 'gross income' of the MCA service provider when it is received or has accrued. 


\subsection{Expenditure incurred by the MCA service provider}

\subsubsection{Initial advance}

The initial advance is the amount the MCA service provider pays to obtain the right, title and interest in the future receivables of the merchant and will be deductible from income if it meets the requirements of section 11 (a) of the Act.

As a starting point it needs to be considered whether the MCA service provider can be said to carry on a 'trade'. In Stone $v$ SIR (1974) 36 SATC 117 at 595, Corbett AJA confirmed that when a taxpayer pursues the trade of a moneylender, money constitutes the circulating capital of the taxpayer. In Solaglass Finance Company (Pty) Limited v CIR (1991) I All SA 339(A), Friedman AJA stated that to determine whether a taxpayer can be said to be carrying on the business of a moneylender, it must be determined if there was an intention to lend to all and sundry and if the lending was done on a system or plan which discloses a degree of continuity. MCAs are offered to the general public and MCA service providers do have a system and a degree of continuity with regard to their transactions. MCA service providers have standard sale and purchase agreements and it is the business objective of the MCA service provider to provide numerous advances. The business of an MCA service provider can be argued to be synonymous with that of a moneylender and could therefore be regarded as the carrying on of a trade. The next consideration would be whether (or not) the expenditure was incurred in the production of income and if it could be regarded as capital in nature.

In granting the initial advance the MCA service provider has the objective to recover an amount in excess of the said initial advance (therefore to realise a profit by means of the discount) as well as to earn income in the form of processing fees. The granting of the MCA could also be argued to be closely linked to the business of a money-lender, in this case the MCA service provider, and consequently in the production of income. In considering whether the initial advance is of a capital nature the distinction between fixed and floating capital is furthermore relevant. The initial advance entitles the MCA service provider to earn the future income (the discount and possible processing fees) and as such creates an income-producing right or asset (representing the tree in the analogy established in CIR $v$ Visser (1937) 8 SATC 271). The intention is to recover the initial advance in full in future as the sales are concluded by the merchant; therefore the initial advance cannot be regarded as floating capital as it would not be consumed or disappear in the process of earning the income (CIRv George Forest Timber Co $L t d$ (1924) I SATC 20). This supports the argument that the initial advance is fixed capital of the MCA service provider and regarded as capital in nature. Consequently the MCA service provider would not be entitled to a deduction in terms of section $11(\mathrm{a})$. The subsequent recovery of the initial advance would constitute a disposal in terms of the Eighth Schedule, but the proceeds and the base cost in terms of this disposal would be the same and would therefore not result in any capital gains tax consequences. In conclusion, the income tax treatment of the initial advance reflects the tax treatment of a traditional loan, as opposed to the common law classification as a specialised form of debt factoring.

The preceding sections investigated the income tax consequences and in the following section the Value-Added Tax (VAT) consequences are investigated. 


\section{VALUE-ADDED TAX CONSEPUENCES}

In addition to income tax a person could also be liable for VAT if required to register as a 'vendor' in terms of section 23 of VAT Act. Registration as a 'vendor' would depend on the value of taxable supplies of such person and the threshold of Rl million prescribed in the VAT Act (SARS, 2015). In the event of the merchant and the MCA service provider not being a 'vendor' there would be no VAT consequences. For the purpose of this article it is, however, assumed that both the merchant and the MCA service provider are VAT 'vendors', in order to formulate possible VAT consequences. As VAT is based on supplies, each of the relevant events of an MCA (indicated in FIGURE 1 ) is dealt with as a separate supply in investigating the VAT consequences for both the merchant and the MCA service provider.

\subsection{Initial advance}

The mere receipt of money does not give rise to any obligation to account for VAT in terms of section 7 of the VAT Act, unless that receipt represents the consideration for a taxable supply of goods or services. The provision of an MCA or the related charges would therefore be a taxable supply if there is a supply of services to the merchant when an MCA agreement is concluded.

The key feature of the MCA agreement is the purchase of the future receivables. For the purchase of future receivables to be a 'service', it must be argued that the purchase involves the MCA service provider 'doing' something. The phrase 'anything done or to be done' in the definition of 'services' is very broad and would include all supplies which are not a supply of corporeal goods. The initial advance itself would therefore constitute a 'service', as it involves making available an advantage or surrender of a right in providing the financing. It needs to be established whether the service in advancing the initial amount could possibly constitute an exempt 'financial service'. Sub-section 1 (c) of the definition of 'financial services' stipulates that 'the transfer of ownership of a debt security' is a 'financial service'. According to Botes and De Wet (2011), debt factoring is merely a form of cession of existing book debts (debts which already exist which are not claimable at the time of the transaction) by a client to the debt factor. The debt factoring transaction will therefore be classified as a 'financial service' provided by the debt factor under sub-section 1 (c). MCA transactions, in comparison to debt factoring, do not relate to existing debt, however, but future debt (debts not in existence at the time of the transaction). In First National Bank of SA Ltd v Lynn NO \& others (1996) it was confirmed that existing and future book debts may be ceded. It is therefore submitted that an MCA transaction can be classified as the transfer of ownership of a debt security according to sub-section 1 (c) of the definition of a 'financial service'.

As an alternative to the preceding argument for inclusion in terms of sub-section $l(c)$ of the definition of a 'financial service', an argument for the inclusion in terms of sub-section $l(f)$ is also submitted. According to sub-section $\mathrm{l}(\mathrm{f})$, the provision by any person of credit under an agreement in terms of which money or money's worth is provided by that person to another person who agrees to pay a sum or sums in the future exceeding in the aggregate the amount of such money or monies' worth also constitutes a 'financial service'. The merchant discharges his obligation by ceding the future credit card receipts to the MCA service provider. It can therefore be argued that this cession is another method of payment - an amount the merchant agrees to pay under a credit agreement as contemplated in sub-section $\mathrm{l}(\mathrm{f})$. It is therefore submitted that the initial advance in terms of an MCA agreement could also resort under sub-section l(f) 
of the definition of a 'financial service' and consequently be regarded as an exempt supply for VAT purposes.

The MCA service provider would therefore not have to account for any output tax on granting of the MCA. Consequently, the merchant would not be entitled to claim any input tax on the initial advance received and subsequently repaid.

\subsection{Discount}

According to SARS (2013:18), the definition of 'financial service' is intended to exempt interest and investment growth, but any fee or similar charge in connection with, ancillary to, or of a complementary nature in relation to the underlying financial instrument is taxable. A discounting cost is not expressly excluded as a 'financial service' in terms of the proviso to section 2 of the VAT Act, which deals with services. It might therefore be inferred that a discount would automatically be regarded as a 'financial service' in terms of the proviso to section 2(1) of the VAT Act. Botes and De Wet (2011) have, however, expressed the view that the 'service' rendered by a debt factoring company when discounting book debts is not a 'financial service' in terms of section 2, as the service does not fall under any of the activities listed as 'financial services'. The position is therefore not conclusive that discounts would automatically be regarded as a 'financial service'.

Botes and De Wet (2011) submit an alternative view for the claim that discounts do not result in VAT consequences: that the discount earned by a debt factor may be viewed as nothing more than a profit made on the purchase of receivables and not the rendering of a 'service' to either the merchant or its future customers. In support of this view, the judgement in CSARS v Cape Consumers (Pty) Ltd (1999) 61 SATC 91 may be applied to MCAs. In the said case the court held that the discount amount (difference between amount received from clients and amount paid to suppliers) constituted no more than a reduced purchase price as a result of prompt payment. The court concluded that nothing was done by Cape Consumers, the taxpayer in the said case, other than to pay the agreed amount to the suppliers. Such an arrangement was held not to fall within the definition of 'services' as defined in the Act and therefore did not attract VAT. It can therefore be argued that the additional amount which accrues to the MCA service provider as a result of retaining the difference between the purchase price of the future receivables and the face value of the receivables (the 'discount'), is no more than a profit made on the purchase of such receivables and not a 'service' rendered to either the merchants or their customers.

It appears, therefore, that the MCA service provider would therefore not have supplied any goods or services in respect of the discounting fee and would accordingly not be liable for any output tax. The merchant would consequently therefore not be entitled to an input tax credit with regard to the discount.

\subsection{Processing fee}

Any consideration payable in the form of a fee, commission, merchant's discount or similar charge (not being a discounting cost or an interest charge) payable over and above the amount attributable to the underlying financial instrument is not deemed to be a financial service (SARS, 2013:18). The processing fee is therefore expressly excluded as 'financial service', as it would be 'any fee'. Accordingly, the processing fee would not be regarded as an exempt supply and constitute a taxable supply for VAT purposes. 
The MCA service provider would therefore have to account for output tax on the processing fee levied. Consequently the merchant would be able to claim input tax to the extent it would be applied for taxable supply purposes.

\subsection{Subsequent sale of goods or rendering of service}

The sale of goods or services by the vendor will be in the course or furtherance of its enterprise and will therefore be subject to VAT at the standard rate (or zero-rated in terms of section 11 of the VAT Act). The merchant will be the vendor rendering the supply to clients and therefore the merchant would be liable for any resulting output tax (if any).

\section{CONCLUSION}

An investigation into the classification of the MCA agreement revealed that, from a common law perspective, it would be a specialised form of debt factoring as opposed to a mere loan agreement. In common with debt factoring, the MCA agreement is a mechanism to access funding with underlying receivables serving as the asset being transferred. The key difference between debt factoring and MCA agreements is that the subject of debt factoring is current or existing receivables, whereas the MCA agreement refers to future receivables.

The initial advance, and resulting discount, would be treated as being similar to a traditional loan for income tax purposes. The merchant would not be taxed on the receipt and the MCA service provider would not be able to deduct the advance granted. Despite the common law classification as a form of debt factoring, the income tax treatment of the initial advance reflects that of a traditional loan. Any processing fee paid by the merchant would be deductible and also included in the 'gross income' of the MCA service provider. The initial advance would, however, not result in any VAT consequences, as the supply of the MCA by the MCA service provider is an exempt supply, as it is a 'financial service', as defined.

The discount in relation to future receivables would be regarded as interest. As such the merchant would qualify for a possible deduction in terms of section 24J(2). The MCA service provider, on the other hand, would include such discount earned in 'gross income' or in terms of section 24J(3), depending on the nature of the MCA service provider and the term of the arrangement. The discount, being interest, would not result in any VAT consequences, as it constitutes an exempt 'financial service' as defined or, alternatively, could be regarded as a discounting profit and therefore not a service for VAT purposes.

The processing fee paid by the merchant would possibly qualify for deduction in terms of section 11(a) of the Act. The MCA service provider would also have to include such receipt in 'gross income' as it would have been received in a scheme of profit-making carrying on a trade similar to that of a money-lender. The charging of the processing fee is specifically excluded from the definition of 'financial services' and is therefore a taxable supply made by the MCA service provider and would therefore result in output tax being levied by the MCA service provider, which in turn could enable the merchant to claim a corresponding input tax deduction in the furthering of taxable supplies.

The sales by the merchant (which result in the receivables which form the subject of the initial advance) would be included in the 'gross income' of the merchant, as the amounts represented by the sales would have accrued to the merchant. The MCA service provider does not have a prior 
entitlement to the sales of the merchant, but rather an entitlement to future payments in respect of the receivables after the income had already accrued to the merchant. The merchant would also have made a supply which could result in output tax for VAT purposes.

In summary, the tax treatment of an MCA was found to differ from traditional debt factoring and the tax treatment of an MCA also mirrored the tax treatment of loans, in respect of the initial advance and the discount. The findings of this study, which are summarised in TABLE 1, could serve as guidance in respect of the tax treatment of MCAs.

TABLE 1: Summary of taxation consequences of MCA transactions

\begin{tabular}{ll}
\hline Merchant & MCA service provider \\
\hline Initial advance &
\end{tabular}

Income tax consequence:

Not included in 'gross income', as it is coupled with an unconditional obligation to repay.

\section{VAT consequence:}

Advance is a 'financial service', therefore an exempt supply (non-taxable) and therefore no VAT consequences.

\section{Income tax consequence:}

Regarded as capital in nature, therefore not deductible in terms of section $11(a)$.

\section{VAT consequence:}

Advance is a 'financial service', therefore an exempt supply (non-taxable) and therefore no VAT consequences.

\section{Discount}

\section{Income tax consequence:}

The discount is incurred for purpose of obtaining working capital for the business. Could be classified as interest and therefore section 23J(2) would apply.

Yield to maturity determines amount allowed as a deduction if section 23J(2) applies.

\section{VAT consequence:}

No VAT consequences, as not regarded as a supply (alternatively regarded as exempt financial service).

\section{Income tax consequence:}

Regarded as interest, therefore application of section 23J(3) needs to be considered.

- If MCA service provider is not a company and the term of the MCA does not exceed one year: included in 'gross income' on accrual basis.

- If the MCA service provider is a company, 24J(3) is applicable: yield-to-maturity basis is applied for inclusion in 'gross income'.

\section{VAT consequence:}

No VAT consequences, as not regarded as a supply (alternatively regarded as exempt financial service).

\section{Processing fee}

\section{Income tax consequence:}

Processing fee is closely linked to income-earning operations; section 11 (a) deduction possible.

\section{VAT consequence:}

Taxable supply by MCA service provider; input tax claim is possible if requirements of VAT Act are

\section{Income tax consequence:}

Included in 'gross income', as earned from a scheme of profit-making in carrying on of a trade.

\section{VAT consequence:}

Taxable supply for VAT purposes (subject to VAT), as specifically excluded from definition of 'financial 


\begin{tabular}{ll}
\multicolumn{1}{c}{ Merchant } & \multicolumn{1}{c}{ MCA service provider } \\
\hline met. & services'. \\
Initial sales by merchant & Income tax consequence: \\
Income tax consequence: & Not 'gross income', as not accrued to the MCA service \\
The gross amount of sales is included in 'gross & provider. \\
income' when sales take place. & VAT consequence: \\
& \\
VAT consequence: & Underlying supply is not made by MCA service \\
Underlying supply is made by merchant. \\
The merchant would levy output tax (unless \\
regarded as exempt supply).
\end{tabular}

Source: Compiled by authors

\section{LIST OF REFERENCES}

Bennett, S. \& Tiku, N. (2008). Thanks, But No Thanks. [Online] Available:

http://www.inc.com/magazine/20080401/thanks-but-no-thanks.html. (Accessed 23 October 2012).

Botes, M.C. \& De Wet, C.G. (2011). Commentary on Value-added Tax, updated as per revision service 9 of 2012 - June 2012. Juta Law Publishers.

BP Southern Africa (Pty) Ltd v CSARS (2007) 69 SATC 79.

Chawira, દ. W. (2011). Taxation of illegal schemes:-should the term 'received by' in the definition of gross income be interpreted with reference to the taxpayers subjective intention? Unpublished Master's thesis. Pretoria: University of Pretoria.

CIR v Genn \& Co (Proprietary) Limited (1955) 20 SATC 113.

CIR v George Forest Timber Co Ltd (1924) I SATC 20.

CIR v People's Stores (Walvis Bay) (Pty) Ltd (1990) 52 SATC 9.

CIR v Visser (1937) 8 SATC 271.

CIR v Witwatersrand Association of Racing Clubs (1960) 23 SATC 380.

CSARS v Cape Consumers (Pty) Ltd (1999) 61 SATC 91.

CSARS v Creative Productions (Pty) Ltd (1999) 61 SATC 106.

Davis, D., Olivier, L. \& Urquhart, G. (2012). Commentary on Income Tax. Juta Law Publishers.

De Koker, A.P. \& Williams, R.C. (2013). 'Chapter 2 Receipts and Accruals, paragraph 2.21, Cession of Income' in Silke on South African Income Tax. [Online] Available:

http://beta.mylexisnexis.co.za.ez.sun.ac.za/Index.aspx\#. (Accessed 200 ctober 2013).

Elandsheuwel Farming (Edms) Bpk v SBI (1978) 39 SATC 163.

Ernst \& Young. (2009). Factoring and forfaiting, a business and regulatory perspective. [Online] Available: http://www.marfinfactors.gr/UserFiles/ernst_and\%20_young_factoring_paper_ 151209.pdf. (Accessed 19 December 2012). 
Everest Merchant Funding (Pty) Ltd. (2011). Do I qualify? [Online] Available: http://everestmerchantfunding.com/do-i-qualify/. (Accessed 21 April 2013).

Farrel, M. (2008). Look Who's Making Coin of the Credit Crisis. [Online] Available: http://www.forbes.com/2008/01/31/cash-advance-goldman-ent-fincx_mf_0131cashadvance.html. (Accessed 28 August 2012).

First Data. (2012). Purchase and Sale for Future Receivables Agreement. [Online] Available: http://www.metrocashsource.com/Merchant-Advance-Purchase-Agreement.pdf. (Accessed 19 December 2012).

First National Bank of SA Ltd v Lynn N0 \& others (1996) (2) SA 339 (A).

Goldin, P. (2007). Never Use The Four Letter Word. Merchant cash advance Blog. [Online] Available: http://merchantcashadvanceblog.blogspot.com/2007/07/never-use-four-letter-word.html. (Accessed 17 February 2013).

Hubbard, J. (2012). Alternative Funding Option for SME's. [Online] Available: http://www.retailcapital.co.za/news/category/print-media/. (Accessed 07 April 2013).

ITC 31 (1924) 2 SATC $52(C)$.

ITC 968 (1961) 24 SATC 726.

ITC 1378 (1983) 45 SATC 230(T).

ITC 1587 (1995) 57 SATC 97.

ITC 1628 (1997) 60 SATC 33.

Kilian, દ. (2014). Merchant cash advances: investigating the taxation consequences in South Africa. Unpublished Master's thesis. Stellenbosch: Stellenbosch University.

Lategan v CIR (1926) 2 SATC 16.

Loten, A. (2011). The Lure of Cash Advances. [Online] Available: http://online.wsj.com/article/SB10001424053111903596904576514500766040470.htm|\#articleTabs \%3Darticle. (Accessed 23 October 2012).

Moodie v CIR (1993) (2) 55 SATC 164.

Nectar Cash-flow Advances. (2012). Merchant/ business cash advance. [Online] Available: http://www.nectaradvances.com/business-cash-advance.php. (Accessed 19 December 2012).

Concise 0xford Dictionary. (2012). Oxford University Press - Oxford Dictionaries Online. [Online] Available: http://oxforddictionaries.com/definition/american_english. (Accessed 19 December 2012).

Republic of South Africa. (1962). Income Tax Act No. 58 of 1962. Pretoria: Government Printers.

Republic of South Africa. (1991). Value-Added Tax Act, No. 89 of 1991. Pretoria: Government Printers.

Risk and Fraud Management Committee of the Electronic Transactions Association. (2008). Merchant Cash Advances White Paper. [Online] Available:

http://www.merchantprocessingresource.com/etabestpractices.htm. (Accessed 230 ctober 2012).

SARS. (2013). Guide for Short-Term Insurance (VAT 421). Legal and Policy Division. Pretoria.

SARS. (2015). Guide for Vendors (VAT 404). Legal and Policy Division. Pretoria.

Solaglass Finance Company (Pty) Limited v CIR (1991) I All SA 339(A). 
Stone v SIR (1974) 36 SATC 117.

Syfrets Bond Participation Bond Managers Ltd v CSARS (2001) 63 SATC 1.

Tozzi, J. (2009). How Merchant Cash Advances Work. [Online] Available:

http://www.businessweek.com/smallbiz/content/jan2009/sb2009018_234392.htm. (Accessed 23 August 2012).

Weston, S. (2012). Advanceme Settlement [Online] Available:

http://www.transactionworld.net/articles/2012/march/legal.asp. (Accessed 23 October 2012). 